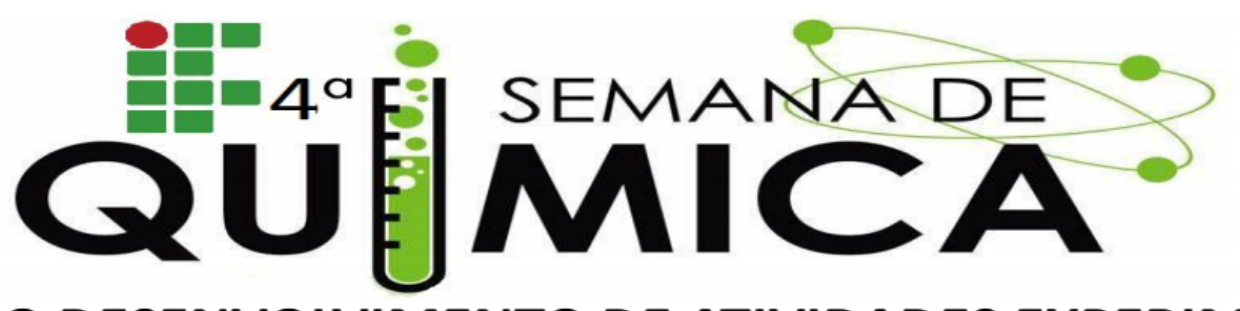

\title{
AVALIAÇÃO DO DESENVOLVIMENTO DE ATIVIDADES EXPERIMENTAIS NO ENSINO DE QUÍMICA PELOS SUPERVISORES DO PROGRAMA PIBID-IFRN- CAMPUS APODI
}

\author{
BARBOSA ${ }^{1}$,P. T. (IFRN). FILHO*2, A. B.(IFRN). FILHO ${ }^{3}$, A. F, ALVES ${ }^{4}$, L. A. (IFRN). BERTINI5, L. M. (IFRN) \\ FERNANDES ${ }^{6}$, P. R. N. (IFRN) \\ Palavras Chave: Atividades Experimentais, Química, PIBID.
}

\section{INTRODUÇÃO}

O professor tem um grande papel de transformar a sociedade, por ser uma figura principal da educação. É através dele a única via de acesso à integração social para todos, e a porta de saída da miséria para as camadas mais humildes da população (SAVIANI, 2000). Atualmente grande parte dos profissionais da Educação, encontram dificuldades para associar a teoria com a prática nos conteúdos ministrados. Diante disso o programa PIBID (Programa Institucional de Bolsas de Iniciação a Docência) que tem como objetivo o desenvolvimento de atividades com os alunos de diferentes escolas, conveniadas com os municípios. Os bolsistas além de adquirirem uma formação do ser professor ao longo da sua graduação, convivem com novas metodologias de ensino. Nesse contexto o presente trabalho tem por finalidade avaliar a importância do programa (PIBID) na elaboração das atividades práticas na Escola Estadual Professor Antônio Dantas e na escola Estadual Professora Maria Zenilda Gama Torres no Município de Apodi/RN.

\section{MATERIAIS E MÉTODOS}

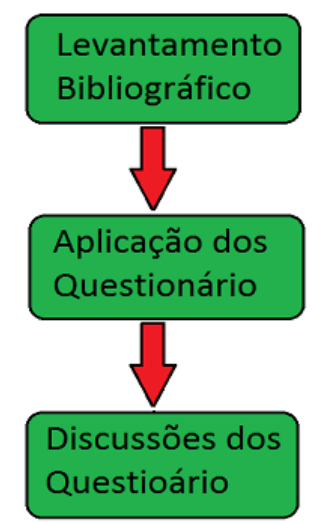

\section{RESULTADOS E DISCUSSÕES}

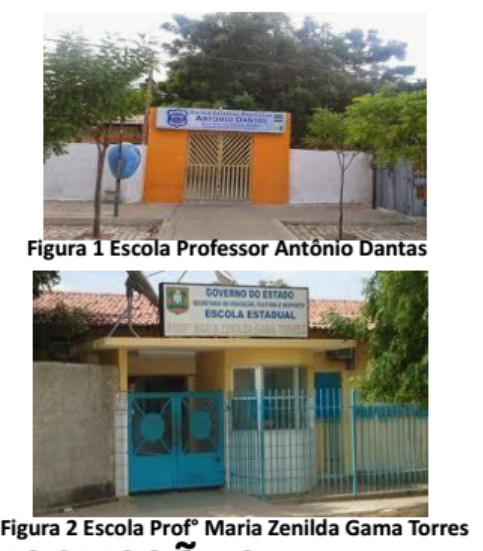

Após aplicar o questionário para os quatro Supervisores sobre o programa analisou-se as respostas, sobre a pergunta: Qual a importância que eles davam às atividades experimentais no ensino de química? Os mesmos classificaram como, "muito importante" no ensino de Química, sendo que torna melhor a aprendizagem do conteúdo abordado. Também apontaram as dificuldades, quando perguntado qual a maior dificuldade encontrada para elaborar atividades experimentais? Como mostra um relato de um dos supervisores abaixo. Supervisor 1; "Um dos maiores problemas está no fato de encontrarmos os materiais adequados para as experiências ocorrerem. Outro problema muito sério reside no fato do tempo. O professor de escola pública precisa trabalhar em dois ou três lugares e isso nos impede de planeja bem essa atividades". Outro problema, é a falta de material adequado nos laboratórios das escolas, inviabilizando a realização das práticas. Os mesmo relataram que quase nunca os realizavam atividades experimentais para seus alunos, de modo que quando passaram a ter ajuda dos bolsistas, essas praticas tornaram muito mais frequentes nas suas aulas, e com os bolsistas PIBID atuando nas escolas ficou mais fácil à elaboração dessas atividades. Ao perguntar o que melhorou, em relação as atividades prática, com os bolsistas PIBID? Os supervisores relataram que houve uma melhora no planejamento das atividades uma maior frequência dessas atividades praticas nas suas aulas, mostrando que o programa vem desenvolvendo boas ações no ensino de Química juntos as professores das escolas beneficiadas.

\section{CONCLUSÃO}

Após aplicação dos questionários observou-se nos relatos feito pelos Supervisores que,os bolsistas PIBID serem bastante participativos nas escolas, estes auxiliam na elaboração e no desenvolvimento das atividades experimentais.

\section{REFERÊNCIAS}

1. SAVIANI, O. Pedagógia histórico-crítica: primeiras aproximações. 7. ed. Campinas, SP: Autores Associados, 2000.

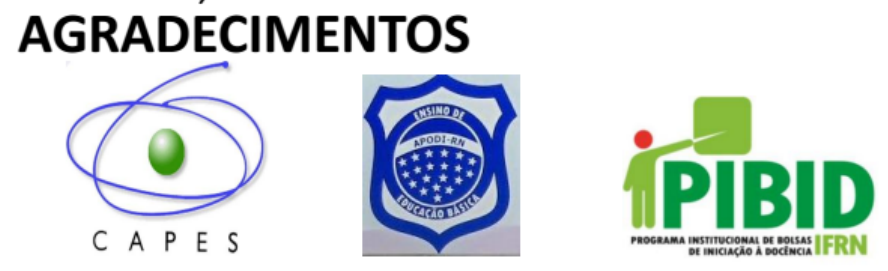

